copper deposits appear very clearly on the scratched $\mathrm{SiO}_{2}$ location, such as in Fig. 7 .

However, the wafer handled with a well designed carrier is scratched shallower, and even by copper decoration method, it is difficult to clarify the origin of copper decoration dot one by one, in order to measure pinhole density normally engendered.

This is the reason why the number of decorations located in the peripheral regions on the examined wafers were not counted to determine the relation between the pinhole densities and the $\mathrm{SiO}_{2}$ thickness, as explained in 3.3.

\section{Conclusion}

An optimum $\mathrm{CuSO}_{4}$ concentration for copper decoration at $40^{\circ} \mathrm{C}$ was $0.01 \mathrm{M}$ under the applied voltage which is derived as a multiplication of the $\mathrm{SiO}_{2}$ thickness and $2.5 \times 10^{6} \mathrm{~V} / \mathrm{cm}$. Under these conditions, the relationship between the pinhole densities and the film thickness was examined, and it was found that the relationship between $\mathrm{SiO}_{2}$ thickness and pinhole density coincides with that obtained by aluminum anodization method. Copper decoration method is indicated as being a convenient method to investigate the origin of pinholes, such as mishandling of a $\mathrm{Si}$ wafer.

\section{Acknowledgements :}

The authors wish to thank Dr. T. Okada and Dr. S. Asanabe for their encouragements and to acknowledge informative discussions with Mr. H. Muta and Mr. H. Tsunemitsu. Dr. N. Kawamura made a number of useful comments for improving the original manuscript. This work is part of the Joint Research Project, sponsored by Musashino Electrical Communication Laboratory, Nippon Telegraph and Telephone Public Corp., Tokyo.

$<$ E463> (Received May 13, 1976)

\section{References :}

1) R.H. Dennard, F.H. Gaensslen, V.L. Rideout, E.B. Bassous, A.R. LeBlanc, IEEE J. Solid-State Circuits sc-9, 256 (1974).

2) W. Kern, Solid-State Technol. 17, March 35(1974).

3) P.J. Besser, J.E. Meinhard, Proc. Symposium on Manufacturing, Phoenix, Arizona, March 1966.

4) W.J. Shannon, RCA Review 121, 431 (1970).

5) Y. Akatsuka, M. Tameda, NEC, unpublished work (1971).

6) M. Kaminaka, S. Takahashi, NEC, unpublished work (1972).

7) S. Takahashi, S. Fujimoto, H. Tsunemitsu, OYO BUTURI 45, 954 (1976).

8) J. Kraitchman, J. Appl. Phys. 38, 4323 (1967).

9) H. Tsunemitsu, H. Shiba, This Journal 40, 493 (1972).

\title{
Formation of $\varepsilon-\mathrm{Fe}_{2} \mathrm{O}_{3}$ in the Vapor Phase Oxidation of Iron (II) Chloride
}

\begin{abstract}
Akio KATO* and Shigeki MATUYA*
The vapor phase oxidation of iron (II) chloride at $700^{\circ} \mathrm{C}$ to $1,000^{\circ} \mathrm{C}$ was found to give $\varepsilon-$ and $\alpha-\mathrm{Fe}_{2} \mathrm{O}_{3}$ as the main products and $\gamma-\mathrm{Fe}_{2} \mathrm{O}_{3}$ as the minor one, in contrast to the oxygenolysis of iron (III) chloride which gives $\eta$ - and $\alpha-\mathrm{Fe}_{2} \mathrm{O}_{3}$ under similar reaction conditions. The formation process of $\mathrm{Fe}_{2} \mathrm{O}_{3}$ particles is discussed.
\end{abstract}

\section{Introduction}

Besides the well-known modifications of $\alpha$ and $r-\mathrm{Fe}_{2} \mathrm{O}_{3}$, the presence of $\varepsilon-\mathrm{Fe}_{2} \mathrm{O}_{3}$ has been reported by several investigaters ${ }^{1)}{ }^{-3}$. In 1934 , Foreister et al. found the formation of magnetic diiron trioxide by the thermal decomposition of $\mathrm{Fe}_{2} \mathrm{O}_{3} \cdot 4 \mathrm{BeO}^{12}$. In 1963 , Schrader et al. found a new diiron trioxide phase, different from $\alpha-$

\footnotetext{
* Department of Applied Chemistry, Faculty of Engineering, Kyushu University (Hakozaki, Fukuoka)
}

and $r$-phases, by electric $\mathrm{d}-\mathrm{c}$ arc discharge between iron electrodes under oxidizing atmosphere and named it $\varepsilon-\mathrm{Fe}_{2} \mathrm{O}_{3}{ }^{2)}$. Later, Trautmann et al. showed that the above two diron trioxides were identical and found a new preparation method of $\varepsilon-\mathrm{Fe}_{2} \mathrm{O}_{3}{ }^{3)}$. In addition, the formation of an another modification, $\eta-\mathrm{Fe}_{2} \mathrm{O}_{3}$, by vapor phase oxygenolysis of iron (III) chloride has recently deen reported ${ }^{4}$.

The present authors found that three kinds of diiron trioxides, $\varepsilon^{-}, \alpha-$ and $\gamma-\mathrm{Fe}_{2} \mathrm{O}_{3}$ were pro- 
duced by the vapor phase oxidation of iron(II) chloride. In this study, the effects of reaction conditions on the formation ratios of these three diiron trioxides were investigated. The results were compared with those of the oxygenolysis of iron (III) chloride.

\section{Experimental}

The reaction was carried out by a flow method. The apparatus is shown in Fig. 1. A silica glass tube was used as the reactor. The furnace consists of two parts, one part (I) for the evaporation of iron chloride and the other (II) for reaction. Anhydrous iron (II) chloride was obtained by the dehydration of $\mathrm{FeCl}_{2} \cdot \mathrm{nH}_{2} \mathrm{O}$ (Wako Junyaku Kogyo, G.R.) at about $250^{\circ} \mathrm{C}$ in dried $\mathrm{N}_{2}$. In the vapor phase oxygenolysis of iron (III) chloride, anhydrous $\mathrm{FeCl}_{3}$ (Ishizu Seiyaku, G.R.) was used without further purification.

$\mathrm{FeCl}_{2}(7-8 \mathrm{~g})$ was evaporated in a mullite boat at $750^{\circ}-900^{\circ} \mathrm{C}$ and carried into the reaction zone by deoxygenated and dried $\mathrm{N}_{2}$, being mixed with $\mathrm{O}_{2}$. In the oxygenolysis of $\mathrm{FeCl}_{3}, \mathrm{FeCl}_{3}(7-8 \mathrm{~g})$ was evaporated in pyrex boat at $250^{\circ}-260^{\circ} \mathrm{C}$. The reaction temperature was between $700^{\circ}$ and $1000^{\circ} \mathrm{C}$. Diiron trioxide powders produced were collected with a $1 l$ flask. The concentrations of iron chlorides in the gas phase were controlled by the evaporation temperatures and determined from the amount of freed $\mathrm{Cl}_{2}$ measured by iodometry. Identification of each diiron trioxide phase in the products was done by $\mathrm{X}$-ray diffraction $(\mathrm{CoK} \alpha)$. The amount of each phase in the product of the oxidation of $\mathrm{FeCl}_{2}$ was

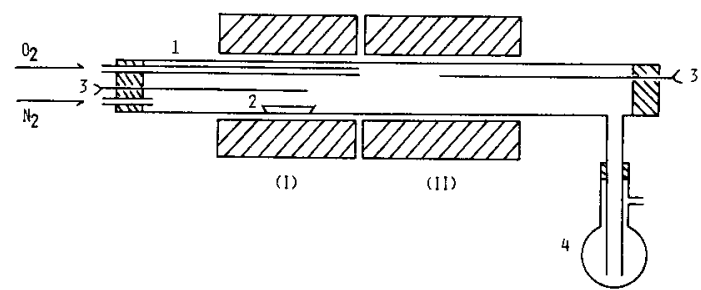

Fig. 1 Aparatus

1 : Silica glasee tube ( $30 \mathrm{~mm}$ I.D.)

$2: \mathrm{FeCl}_{2}$ or $\mathrm{FeCl}_{3}$ source

3 : CA thermocouple

4 : Collecting flask ( $1 l$ ), ( I ) : Evaporation zone (II) : Reaction zone determined from the intensity of the strongest line of each phase $\left(\varepsilon-\mathrm{Fe}_{2} \mathrm{O}_{3}:(420), \alpha-\mathrm{Fe}_{2} \mathrm{O}_{3}\right.$ : (104), $\left.r-\mathrm{Fe}_{2} \mathrm{O}_{3}:(311)\right)^{* 1}$. The contents of $\mathrm{Fe}^{3+}$ and $\mathrm{Fe}^{2+}$ in the products were determined dy titration with $0.01 \mathrm{M}$ EDTA and $0.05 \mathrm{~N} \mathrm{KMnO}_{4}$, respectively.

\section{Results and Discussion}

In the vapor phase oxidation of iron(II) chloride, $\varepsilon^{-}$and $\alpha-\mathrm{Fe}_{2} \mathrm{O}_{3}$ are the main products and $\gamma-\mathrm{Fe}_{2} \mathrm{O}_{3}$ is the minor one. On the other hand, in the case of iron (III) chloride, $\eta^{-}$and $\alpha-\mathrm{Fe}_{2} \mathrm{O}_{3}$ are produced under similar conditions, as reported by Funaki et al. ${ }^{4)}$. The identifications of reaction products by $\mathrm{X}$-ray diffraction are illustrated in Table 1. The degree of reduction of iron in the products is less than $2 \%$ even in the oxidation of $\mathrm{FeCl}_{2}$.

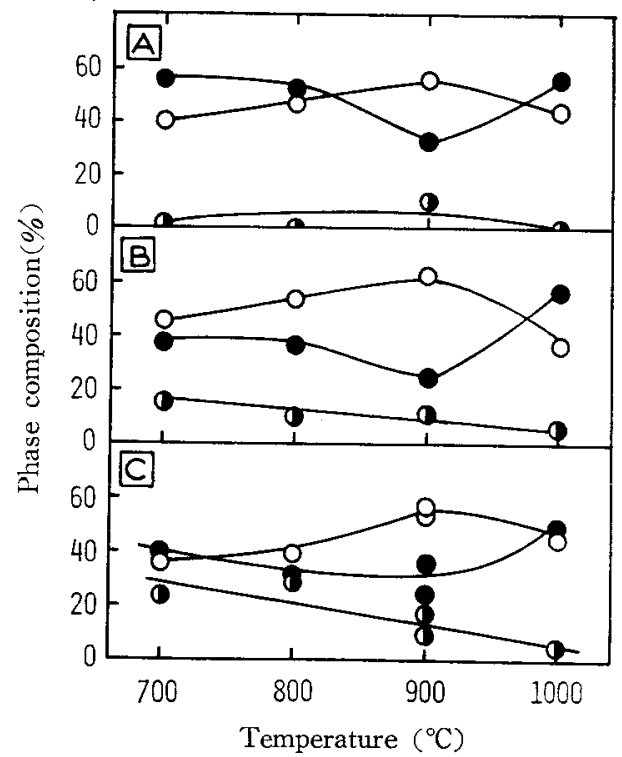

Fig. 2 Reaction temperature and phase composition of $\mathrm{Fe}_{2} \mathrm{O}_{3}$ powders

$\left[\mathrm{FeCl}_{2}\right]=0.8 \sim 1.4(\%),\left[\mathrm{O}_{2}\right] ;(\mathrm{A})=40 \%,(\mathrm{~B})=$ $60 \%,(\mathrm{C})=80 \%$, Gas flow rate; $500 \mathrm{ml} / \mathrm{min}$ $\bigcirc: \varepsilon-\mathrm{Fe}_{2} \mathrm{O}_{3}, \mathrm{O}: \alpha-\mathrm{Fe}_{2} \mathrm{O}_{3}, \quad\left(\gamma-\mathrm{Fe}_{2} \mathrm{O}_{3}\right.$

*1 The itensity ratio of the strongest line of each phase was found as; $\mathrm{I}_{\alpha-\mathrm{Fe}_{2} \mathrm{O}_{3}(104)}: \mathrm{I}_{\gamma-\mathrm{Fe}_{2} \mathrm{O}_{3}(311)}: \mathrm{I}_{s-\mathrm{Fe}_{2} \mathrm{O}_{3}(420)}=$ $1.00: 1.33 \pm 0.05: 1.08 \pm 0.10$. For the overlap of (311) of $\gamma-\mathrm{Fe}_{2} \mathrm{O}_{3}$ and (110) of $\alpha-\mathrm{Fe}_{2} \mathrm{O}_{3}$, the measured ratio, $\mathrm{I}_{\alpha-\mathrm{Fe}_{2} \mathrm{O}_{3}(110)} / \mathrm{I}_{\alpha-\mathrm{Fe}_{2} \mathrm{O}_{8}(104)}=0.61 \pm 0.03$, was used for the correction. However, there is also a partial overlap between (104) of $\alpha-\mathrm{Fe}_{2} \mathrm{O}_{3}$ and (420) of $\varepsilon-\mathrm{Fe}_{2} \mathrm{O}_{3}$. Then, it seems to be difficult to analyze the mixture of $\alpha, \gamma$, and $\varepsilon$ phases better than $10 \%$ accuracy as indicated by Schrader et al. ${ }^{2}$. 
Table $1 \mathrm{X}$-ray diffraction patterns of reaction products

\begin{tabular}{|c|c|c|c|c|c|c|c|c|c|c|c|c|c|}
\hline \multirow{2}{*}{\multicolumn{2}{|c|}{ Product $A^{a)}$}} & \multicolumn{6}{|c|}{ Reference } & \multirow{2}{*}{\multicolumn{2}{|c|}{ Product $B^{b)}$}} & \multicolumn{4}{|c|}{ Reference } \\
\hline & & \multicolumn{2}{|c|}{$\alpha-\mathrm{Fe}_{2} \mathrm{O}_{3}{ }^{\mathrm{c})}$} & \multicolumn{2}{|c|}{$\varepsilon-\mathrm{Fe}_{2} \mathrm{O}_{3}{ }^{\mathrm{d})}$} & \multicolumn{2}{|c|}{$\gamma-\mathrm{Fe}_{2} \mathrm{O}_{3}{ }^{\mathrm{e}}$} & & & \multicolumn{2}{|c|}{$\alpha-\mathrm{Fe}_{2} \mathrm{O}_{3}{ }^{\mathrm{c})}$} & \multicolumn{2}{|c|}{$\left.r-\mathrm{Fe}_{2} \mathrm{O}_{3}{ }^{\mathrm{f}}\right)$} \\
\hline $\mathrm{d}(\AA)$ & I & $\mathrm{d}(\AA)$ & I & $d(\AA)$ & $I$ & $\mathrm{~d}(\AA)$ & I & $\mathrm{d}(\AA)$ & I & $\mathrm{d}(\AA)$ & I & $\mathrm{d}(\AA)$ & I \\
\hline 3.67 & 20 & 3.66 & 25 & & & & & 3.85 & 20 & & : & 3.84 & 20 \\
\hline 3.22 & 20 & & & 3.24 & 20 & & & 3.68 & 10 & 3.66 & 25 & & \\
\hline 2.97 & 30 & & & 2.98 & 35 & & & 2.71 & 100 & 2.69 & 100 & 2.72 & 100 \\
\hline 2.95 & 5 & & & & & 2.95 & 34 & 2.52 & 25 & 2.51 & 50 & 2.53 & 10 \\
\hline 2.73 & 90 & & & 2.73 & 100 & & & 2.21 & 10 & 2.20 & 30 & 2.21 & 10 \\
\hline 2.70 & 60 & 2.69 & 100 & & & & & 2.00 & 10 & & & 2.00 & 10 \\
\hline 2.57 & 10 & & & 2.57 & 8 & & & 1.84 & 20 & 1.84 & 40 & 1.85 & 10 \\
\hline 2.54 & 10 & & & 2.55 & 20 & & & 1.70 & 15 & 1.69 & 60 & & \\
\hline 2.52 & 100 & 2.51 & 50 & & & 2.52 & 100 & 1.66 & 30 & & & 1.66 & 40 \\
\hline 2.45 & 30 & & & 2.46 & 30 & & & 1.49 & 10 & 1.48 & 35 & & \\
\hline 2.30 & 5 & & & 2.30 & 6 & & & & & & & & \\
\hline 2.24 & 20 & & & 2.24 & 20 & & & & & & & & \\
\hline 2.21 & 20 & 2.20 & 30 & & & & & & & & & & \\
\hline 2.17 & 5 & & & 2.17 & 14 & & & & & & & & \\
\hline 2.09 & 15 & & & & & 2.08 & 24 & & & & & & \\
\hline 1.98 & 10 & & & 1.98 & 20 & & & & & & & & \\
\hline 1.84 & 20 & 1.84 & 40 & & & & & & & & & & \\
\hline 1.73 & 10 & & & 1.74 & 25 & & & & & & & & \\
\hline 1.69 & 30 & 1.69 & 60 & & & 1.70 & 12 & & & & & & \\
\hline 1.66 & 10 & & & 1.67 & 25 & & & & & & & & \\
\hline 1.61 & 15 & & & & & 1.61 & 33 & & & & & & \\
\hline 1.52 & 25 & & & 1.52 & 35 & & & & & & & & \\
\hline 1.49 & 10 & 1.48 & 35 & & & & & & & & & & \\
\hline 1.47 & 20 & & & & & 1.48 & 53 & & & & & & \\
\hline
\end{tabular}

a) Reaction product of $\mathrm{FeCl}_{2}-\mathrm{O}_{2}$ system at $900^{\circ} \mathrm{C}$,

c) ASTM card 13-534, d) ASTM card 16-653,

b) Reaction product of $\mathrm{FeCl}_{3}-\mathrm{O}_{2}$ system at $700^{\circ} \mathrm{C}$

3.1 Effects of reaction conditions on the formation ratio of each diiron trioxide phase

Although the determination of the amount of each phases in reaction products accompanies a considerable error*2, one can see the following tendencies between the reaction conditions and the formation ratio of $\alpha . \gamma$, and $\varepsilon$ phases.

The effect of reaction temperature is shown in Fig. 2. The yield of $\varepsilon-\mathrm{Fe}_{2} \mathrm{O}_{3}$ shows a maximum and that $\alpha-\mathrm{Fe}_{2} \mathrm{O}_{3}$ shows a minimum at around $900^{\circ} \mathrm{C}$. Figure 3 illustrates the effect of oxygen concentration at $900^{\circ} \mathrm{C}$. Similar trends could be seen at $800^{\circ} \mathrm{C}$. The effect of oxygen concentration was little at $700^{\circ} \mathrm{C}$ and $1000^{\circ} \mathrm{C}$, except that the yield of $r-\mathrm{Fe}_{2} \mathrm{O}_{3}$ increased with

*2 See *1.

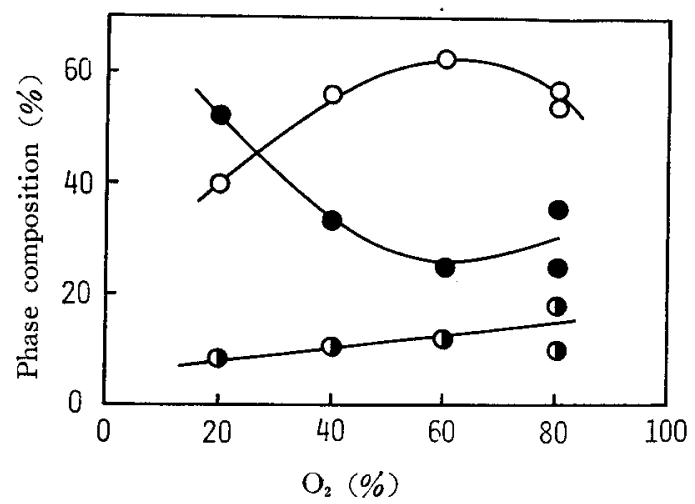

Fig. 3 Oxygen concentration and phase composition of $\mathrm{Fe}_{2} \mathrm{O}_{3}$ powders

Reaction temperature; $900^{\circ} \mathrm{C}, \quad\left[\mathrm{FeCl}_{2}\right]=0.9 \sim$ 1.1 vol\% (balance: $\mathrm{N}_{2}$ ), Gas flow rate: 500 $\mathrm{ml} / \mathrm{min}$. Symbols are the same as in Fig. 2 


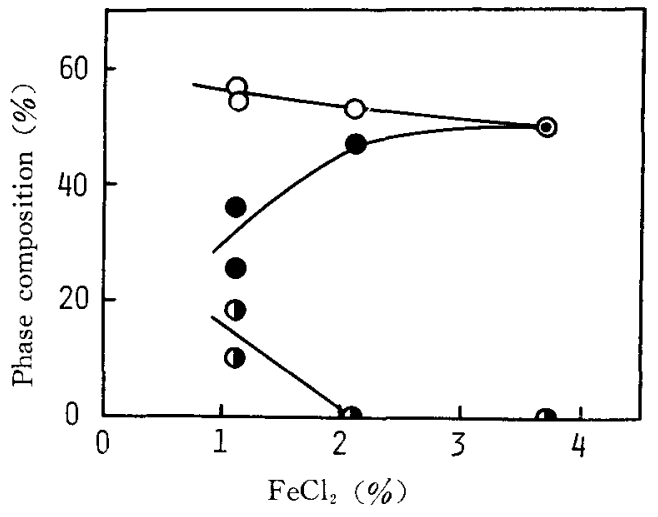

Fig. $4 \mathrm{FeCl}_{2}$ concentration and phase composition of $\mathrm{Fe}_{2} \mathrm{O}_{3}$ powders

Reaction temperature: $900^{\circ} \mathrm{C},\left[\mathrm{O}_{2}\right]=80 \mathrm{vol} \%$ (balance: $\mathrm{N}_{2}$ ), Gas flow rate: $500 \mathrm{ml} / \mathrm{min}$.

Symbols are the same as in Fig. 2

rise in oxygen concentration at $700^{\circ} \mathrm{C}$. The effect of $\mathrm{FeCl}_{2}$ concentration is shown in Fig. 4. The formation of $r-\mathrm{Fe}_{2} \mathrm{O}_{3}$ occurs only when $\mathrm{FeCl}_{2}$ concentration is low. The gas flow rate $(300,500,900 \mathrm{ml} / \mathrm{min})$ affected little on the yield of three phases.

\subsection{Electron microscopic observation}

Electron micrographs of the products are given in Fig. 5. The particles have linear edges, suggesting that they are single crystalline. The particle sizes lie between a few thousand $\AA$ and $2 \mu$. As seen in Fig. 5 and Table 2, the sizes increase with rise in reaction temperature and $\mathrm{FeCl}_{2}$ concentration, but vary little with oxygen concentration.

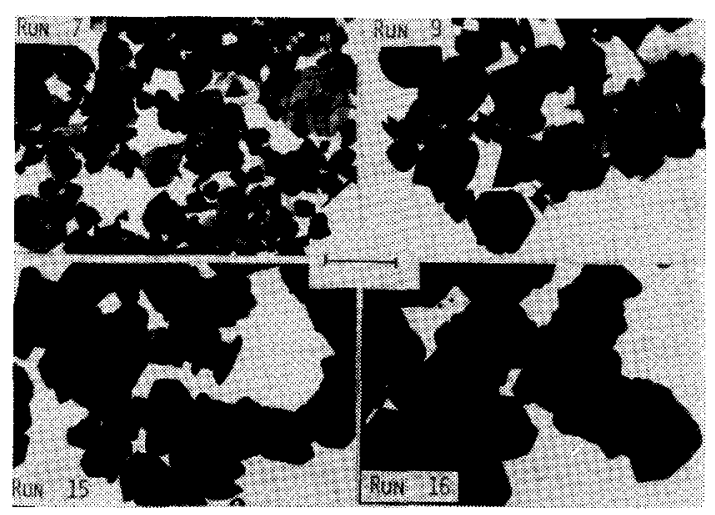

Fig. 5 Electron micrographs of $\mathrm{Fe}_{2} \mathrm{O}_{3}$ powders (scale; $1 \mu \mathrm{m}$ ) (Reaction condition is given in Table 2)
Table 2 Particle size

\begin{tabular}{|c|c|c|c|c|}
\hline \multirow{2}{*}{ Run } & \multirow{2}{*}{$\begin{array}{c}\text { Reaction } \\
\text { temperature } \\
\left({ }^{\circ} \mathrm{C}\right)\end{array}$} & \multicolumn{2}{|c|}{$\begin{array}{l}\text { Gas composition a) } \\
\quad\left(\text { balance: } \mathrm{N}_{2} \text { ) }\right.\end{array}$} & \multirow{2}{*}{$\begin{array}{c}\text { Mean } \\
\text { diameter } \\
(\mu \mathrm{m})\end{array}$} \\
\hline & & $\begin{array}{l}\mathrm{FeCl}_{2} \\
(\operatorname{vol} \%)\end{array}$ & $\begin{array}{c}\mathrm{O}_{2} \\
(\operatorname{vol} \%)\end{array}$ & \\
\hline 4 & 700 & 1.0 & 80 & 0.3 \\
\hline 7 & 800 & 0.8 & 80 & 0.4 \\
\hline 8 & 900 & 1.0 & 20 & 0.7 \\
\hline 9 & 900 & 1.0 & 40 & 0.6 \\
\hline 10 & 900 & 0.9 & 60 & 0.6 \\
\hline 11 & 900 & 1.1 & 80 & 0.7 \\
\hline 14 & 1000 & 1.0 & 80 & 0.6 \\
\hline 15 & 900 & 1.1 & 80 & 0.8 \\
\hline 16 & 900 & 2.1 & 80 & 1.3 \\
\hline 17 & 900 & 3.7 & 80 & 1.6 \\
\hline
\end{tabular}

a) Gas flow rate, $500 \mathrm{ml} / \mathrm{min}$

b) Number-averaged diameter of about 50 particles from 3-4 electron micrographs

\subsection{Formation process of diiron trioxide particles}

The particle formation in vapor phase reaction consists of two processes; homogeneous nucleation and growth. In the case of vapor phase oxidation of $\mathrm{FeCl}_{2}$, a cluster of diiron trioxide, $\left(\mathrm{Fe}_{2} \mathrm{O}_{3}\right)_{\mathrm{n}}$, is formed and grows into a diron trioxide partice through the critical nucleus.

$$
\begin{array}{ll}
\mathrm{FeCl}_{2}-\frac{\mathrm{O}_{2}}{\mathrm{FeCl}_{2}, \mathrm{O}_{2}} & \left(\mathrm{Fe}_{2} \mathrm{O}_{3}\right)_{\mathrm{n}} \\
\left(\mathrm{Fe}_{2} \mathrm{O}_{3}\right)_{\mathrm{n}} \stackrel{\left.\mathrm{Fe}_{2} \mathrm{O}_{3}\right)_{\infty}}{\longrightarrow}
\end{array}
$$

The equilibrium constants of the oxidation of $\mathrm{FeCl}_{2}$ and the related reactions are shown in Fig. 6. The oxidation of $\mathrm{FeCl}_{2}$ is exothermic and the thermodynamic driving force decreases with rise in temperature. This may be responsible for the increase in particle sizes, that is, the decrease in the nucleation, with rise in reaction temperature.

In the vapor phase oxidation of $\mathrm{FeCl}_{2}$, three kinds of phases, $\varepsilon^{-}, \gamma^{-}$and $\alpha-\mathrm{Fe}_{2} \mathrm{O}_{3}$ are formed. $\alpha-\mathrm{Fe}_{2} \mathrm{O}_{3}$ is the most stable and the others metastable (Fig. 6). It has been reported that $\varepsilon-$ and $r-\mathrm{Fe}_{2} \mathrm{O}_{3}$ are transformed into $\alpha-\mathrm{Fe}_{2} \mathrm{O}_{3}$ at about $750^{\circ} \mathrm{C}^{33,5)}$ and at $400^{\circ} \mathrm{C}-700^{\circ} \mathrm{C}^{6)-8)}$, respectively. In the present study, the reaction product at $800^{\circ} \mathrm{C}$ (Fig. 2 B) was transformed completely into $\alpha-\mathrm{Fe}_{2} \mathrm{O}_{3}$ by heating at $550^{\circ} \mathrm{C}$ for $5 \mathrm{~min}$ in air. In the temperature range $700^{\circ} \mathrm{C}$ $900^{\circ} \mathrm{C}$, however, the yield of $\varepsilon-\mathrm{Fe}_{2} \mathrm{O}_{3}$ increases 


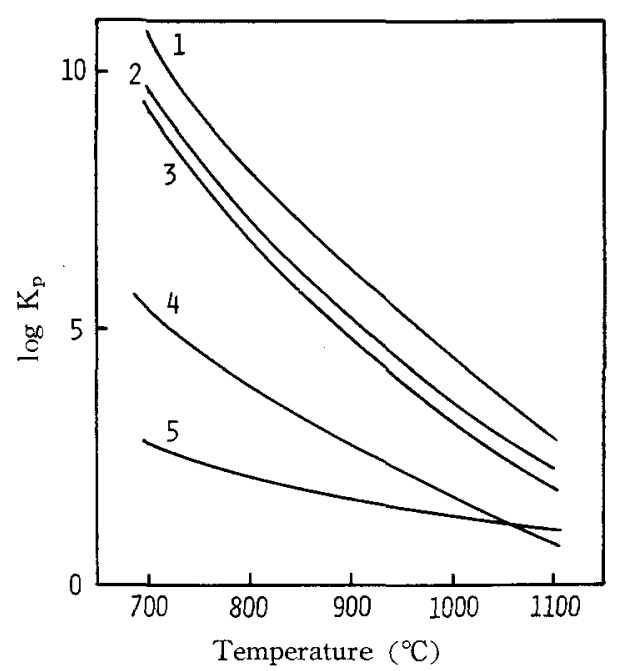

Fig. 6 Equilibrium constants of related reactions

1: $2 \mathrm{FeCl}_{2}(\mathrm{~g})+3 / 2 \mathrm{O}_{2}(\mathrm{~g})=\alpha-\mathrm{Fe}_{2} \mathrm{O}_{3}(\mathrm{~s})+2 \mathrm{Cl}_{2}(\mathrm{~g})$

2: $2 \mathrm{FeCl}_{2}(\mathrm{~g})+3 / 2 \mathrm{O}_{2}(\mathrm{~g})=r-\mathrm{Fe}_{2} \mathrm{O}_{3}(\mathrm{~s})+2 \mathrm{Cl}_{2}(\mathrm{~g})$

$3: 2 \mathrm{FeCl}_{2}(\mathrm{~g})+3 / 2 \mathrm{O}_{2}(\mathrm{~g})=\varepsilon-\mathrm{Fe}_{2} \mathrm{O}_{3}(\mathrm{~s})+2 \mathrm{Cl}_{2}(\mathrm{~g})$

4: $2 \mathrm{FeCl}_{3}(\mathrm{~g})+3 / 2 \mathrm{O}_{2}(\mathrm{~g})=\alpha-\mathrm{Fe}_{2} \mathrm{O}_{3}(\mathrm{~s})+3 \mathrm{Cl}_{2}(\mathrm{~g})$

5: $\mathrm{FeCl}_{2}(\mathrm{~g})+1 / 2 \mathrm{Cl}_{2}(\mathrm{~g})=\mathrm{FeCl}_{3}(\mathrm{~g})$

The heat of formation of $\mathrm{Fe}_{2} \mathrm{O}_{3}(\mathrm{~s}), \Delta \mathrm{H}_{298}^{\circ}$ (Kcal (mole $)=-196.4(\alpha)),-191.7(\gamma)$, and $\left.-186.6(\varepsilon)^{9}\right)$ are used and the entropy and heat capacity of $r^{-}$and $\varepsilon$-phases are assumed as the same with $\alpha$-phase. Other values are taken from JANAF Thermochemical Table

and that of $r-\mathrm{Fe}_{2} \mathrm{O}_{3}$ changes little with rise in reaction temperature. In the vapor phase oxidation of $\mathrm{FeCl}_{2}$ in this temperature range, therefore, the nucleation of each phase, $\varepsilon^{-}, \gamma^{-}$and $\alpha-\mathrm{Fe}_{2} \mathrm{O}_{3}$, occurs independently, the transformation of $\varepsilon$ - and $\gamma-\mathrm{Fe}_{2} \mathrm{O}_{3}$ into $\alpha$-phase being considered to be small. At $1,000^{\circ} \mathrm{C}$ where the yield of $\alpha-\mathrm{Fe}_{2} \mathrm{O}_{3}$ increases, there is a possibility of partial transformation of $\varepsilon$ - or $\gamma-\mathrm{Fe}_{2} \mathrm{O}_{3}$ into $\alpha$-phase.

On the oxygenolysis of $\mathrm{FeCl}_{3}$, the following results are obtained.

$\left[\mathrm{FeCl}_{3}\right]=2.0 \sim 2.3 \mathrm{vol} \%, \quad\left[\mathrm{O}_{2}\right]=80 \mathrm{vol} \%$

(balance; $\mathrm{N}_{2}$ ).

Reaction temperature; $700^{\circ} \mathrm{C} 900^{\circ} \mathrm{C}$

$\begin{array}{lll}\text { Intensity ratio } & 0.5 & 0.1\end{array}$

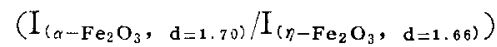

The $\eta$-phase formed was completely transformed into $\alpha-\mathrm{Fe}_{2} \mathrm{O}_{3}$ by heating in air at $600^{\circ} \mathrm{C}$ for an hour. However, the yield of $\eta-\mathrm{Fe}_{2} \mathrm{O}_{3}$ at $900^{\circ} \mathrm{C}$ is greater than that at $700^{\circ} \mathrm{C}$. In the oxy- genolysis of $\mathrm{FeCl}_{3}$, accordingly, the nucleation of $r_{-}$and $\alpha-\mathrm{Fe}_{2} \mathrm{O}_{3}$ also occurs independently.

The over-all reactions of $\mathrm{FeCl}_{2}$ and $\mathrm{FeCl}_{3}$ with oxygen are represented by eqs. (3) and (4), respectively.

$$
\begin{aligned}
2 \mathrm{FeCl}_{2}(\mathrm{~g}) & +3 / 2 \mathrm{O}_{2}(\mathrm{~g}) \\
& =\mathrm{Fe}_{2} \mathrm{O}_{3}(\mathrm{~s})+2 \mathrm{Cl}_{2}(\mathrm{~g}) \\
2 \mathrm{FeCl}_{3}(\mathrm{~g}) & +3 / 2 \mathrm{O}_{2}(\mathrm{~g}) \\
= & \mathrm{Fe}_{2} \mathrm{O}_{3}(\mathrm{~s})+3 \mathrm{Cl}_{2}(\mathrm{~g})
\end{aligned}
$$

It should be noted here that in the oxidation of $\mathrm{FeCl}_{2}$ there may be formed a considerable amount of $\mathrm{FeCl}_{3}$ by reaction between $\mathrm{FeCl}_{2}$ and freed $\mathrm{Cl}_{2}$. The formation of $\mathrm{FeCl}_{3}$ by eq. (5) is

$$
\mathrm{FeCl}_{2}(\mathrm{~g})+1 / 2 \mathrm{Cl}_{2}(\mathrm{~g})=\mathrm{FeCl}_{3}(\mathrm{~g})
$$

favorable thermodynamically in the temperature range examined (Fig. 6). The oxidation of $\mathrm{FeCl}_{2}$ should, therefore, be generally represented by

$$
\begin{gathered}
(2-\mathrm{a}) \mathrm{FeCl}_{2}(\mathrm{~g})+\mathrm{aFeCl}_{3}(\mathrm{~g})+3 / 2 \mathrm{O}_{2}(\mathrm{~g}) \\
=\mathrm{Fe}_{2} \mathrm{O}_{3}(\mathrm{~s})+(2+\mathrm{a} / 2) \mathrm{Cl}_{2}(\mathrm{~g})
\end{gathered}
$$

The ratio, $\mathrm{Fe}$ (II) $/ \mathrm{Fe}$ (II) $+\mathrm{Fe}$ (III), in diiron trioxide formed by arc discharge of iron electrodes is very small $\left(0.57 \times 10^{-3}\right)^{2)}$. The formation reaction is represented by

$$
2 \mathrm{Fe}(\mathrm{g})+3 / 2 \mathrm{O}_{2}(\mathrm{~s})=\mathrm{Fe}_{2} \mathrm{O}_{3}(\mathrm{~s})
$$

Of the formation reactions of $\mathrm{Fe}_{2} \mathrm{O}_{3}$, eqs. (3) or (6) and (7) give metastable phases, $\varepsilon-$ and $\gamma-\mathrm{Fe}_{2} \mathrm{O}_{3}$, and eq. (4) a metastable phase, $\eta-$ $\mathrm{Fe}_{2} \mathrm{O}_{3}$. Eqs. (3) or (6) and (7) differ from eq. (4) in that the oxidation states of iron in the reactants are lower than those in the products. This suggests that the nucleation of $\varepsilon-$ and $r-$ $\mathrm{Fe}_{2} \mathrm{O}_{3}$ is only possible when $\mathrm{Fe}$ (II) exists. The composition of $\varepsilon$ - and $\gamma-\mathrm{Fe}_{2} \mathrm{O}_{3}$ clusters can be expressed by $\mathrm{Fe}$ (II ) ${ }_{\mathrm{y}} \mathrm{Fe}$ (III) $)_{2-\mathrm{x}} \mathrm{O}_{3}$. The structure of $r-\mathrm{Fe}_{2} \mathrm{O}_{3}$ cluster may be similar to that of $\mathrm{Fe}_{3} \mathrm{O}_{4}$. Although the nucleation of $\varepsilon^{-}$and $\gamma^{-}$ phasas requires the existence of $\mathrm{Fe}$ (II), no tendency for yields of these two phases to increase as oxygen concentration decreases or $\mathrm{FeCl}_{2}$ concentration increases was observed and the gas composition affects the yields of these metastable phases in a different way. In the oxidation of $\mathrm{FeCl}_{2}$, the yields of $\varepsilon$ - and $\gamma$-phases change little or increase with oxygen concentration. Further, the yield of $\varepsilon$-phase is approximately constant and that of $\gamma$-phase decreases with $\mathrm{FeCl}_{2}$ concentration. In the arc discharge method, $\varepsilon$ - and $\alpha$-phases increase and $\gamma-\mathrm{Fe}_{2} \mathrm{O}_{3}$ decreases as oxygen concentration increases ${ }^{2}$. 
The formation mechanism of $\mathrm{Fe}_{2} \mathrm{O}_{3}$ particles, then, needs further investigations.

The formation of $\varepsilon$ - and $r-\mathrm{Fe}_{2} \mathrm{O}_{3}$ in the oxidation of iron(II) chloride is observed only in the vapor phase reaction. When iron (II) chloride $\left(\mathrm{mp} .677^{\circ} \mathrm{C}\right.$ ) was oxidized in the solid state $\left(\right.$ at $600^{\circ} \mathrm{C}$ ) or in the liquid state $\left(\right.$ at $720^{\circ} \mathrm{C}$ ) in $\mathrm{O}_{2}$ of $1 \mathrm{~atm}$ for $5 \mathrm{~min}$, the products were exclusively $\alpha-\mathrm{Fe}_{2} \mathrm{O}_{2}$. In the solid and liquid states, the cluster of $\varepsilon-$ or $r-\mathrm{Fe}_{2} \mathrm{O}_{3}$, if produced, may state for a longer time at these high temperatures and be transformed into $\alpha-\mathrm{Fe}_{2} \mathrm{O}_{3}$ structure. In the vapor phase oxidation, on the other hand, the clusters or particles produced leave the high temperature zone in a short time, resulting in the high yield of 'metastable phases.

Acknowledgement :

This research was supported in part by the Science
Foundation of the Ministry of Education (No.885150 and 185177).

$$
<\text { E 477 }>\text { (Received Aug. 9, 1976) }
$$

\section{Reference :}

1) H. Foreister, G. Guiot-Guillain, C.R. Acad. Sci. 199, 720 (1934).

2) R. Schrader, G. Buttner, Z. anorg. allg. Chem. 320, 220 (1963).

3) J.M. Trautmann, H. Foreister, C.R. Acad. Sci. 261, 4423 (1965).

4) K. Funaki, Y. Saeki, T. Nakai, Denkı Kagaku 40, 73 (1972).

5) I. Dezsi, J.M.D. Coey, phys. stat sol. (a) 15, 681 (1973).

6) S. Kachi, K. Momiyama, S. Shimizu, J. Phys. Soc. Japan 18, 106 (1963).

7) W. Feitknecht, U. Mannweiler, Helv. Chim. Acta 50, 570 (1967)

8) R. Furuichi, J. Ishii, F. Sato, Kogyo Kagaku Zasshi 74, 103 (1971).

9) J.M. Trautmann, Bull. Soc. Chim. France 1966, 922 .

\section{酸性水溶液中の鉄の腐食におよぼす交流の影響*}

\begin{abstract}
1 緒言 (Introduction)
酸性もしくは中性水溶液中の鉄の腐食に関しては多く の研究によりその反応機構も明らか加されている反面, 同環境下の交流腐食に関しては基礎的研究が少なく，そ の電気化学的挙動について浪解明されていない点が多 い. 中でも交流腐食の発生要因として重要な鉄の複合電 極反応系に対する交流電流の作用については理論的 ${ }^{12,2)}$ または実験的 ${ }^{3}$ に追究されているが，現象が複雑である

そこで本報では硫酸水溶液中の鉄の腐食が複合電極反 忘として進行する過程で，これに加わる微小交流電流が 分極特性におよぼす影響を実験的化確かめ，合せて環境
\end{abstract} ためまだ体系的な考察は行なわれていない． 因子との関倸について考察した.

\section{2 実験 (Experimental)}

実験法打もに大気開放下の $0.1 \mathrm{M} \mathrm{H}_{2} \mathrm{SO}_{4}$ 溶液 (液温

* 鉄の交流腐食汇関 -る る研究（第 1 報） Studies on Alternating Current Corrosion of Iron(Part 1)

** 大日日本電線株式会社電気研究所（引崎市川崎区日進町 12)

\section{鳥越泰㷋}

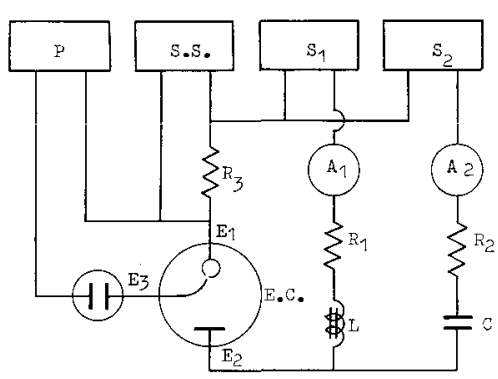

Fig. 1 Experimental circuit
$\mathrm{S}_{1}:$ DC Source,
EC. : Electrolytic cell
$\mathrm{S}_{2}:$ AC Source,
$\mathrm{E}_{1}$ : Test electrode
$\mathrm{R}_{1}, \mathrm{R}_{2}, \mathrm{R}_{3}$ : Resistor,
L : Choke coil,
$\mathrm{E}_{2}$ : Auxiliary electrode
$\mathrm{C}$ : Condenser,
$\mathrm{E}_{3}$ : Reference electrode
$\mathrm{A}_{1}: \mathrm{DC}$ Milliammeter,
S.S. : Synchro-Scope
$\mathrm{A}_{2}: \mathrm{AC}$ Microammeter

$\left.20 \pm 0.2^{\circ} \mathrm{C}\right)$ 中の静止電極について行ない，また溶存酸 素濃度の異なる各条件下で実験を補足した。拉もな実験 として交流成分を有する分極電流により鉄の分極特性を 準定常法で求めた．その実験回路をFig. 1 亿示与. 電源 には直流電源と正弦波交流電源の並列回路を用いたが, 